\section{THE MAKING OF MOUNTAINS,}

THE profound impression made on contemporary geological thought by what is known as the SchardtLugeon theory of ovgrf $1 \mathrm{ldjg}$ is well seen in Herr H.
Hoek's last paper ph (Berichte d.ANaturfonsd. Gesell. zu Freiburg i. B., Bd. xvi., 1906, In this he completely modifies his reading of teclistift, published three years ago, in favour of one that brings $t$ into structural harmony with recent views as to the etistence of "Ueberschiebungsdecken," "Nappes de recouvrement," or overlapping and overthrust recumbent folds. The region south-east of Chur has received a good deal of geological attention, and Herr Hoek claims that it now falls into its place as a structural link between the overfolded areas of Switzerland and the Austrian Alps. His paper is written in a considerately argumentative spirit that provides cheerful reading, and concludes with a tilt at Rothpletz, who has sprung into the same field of inquiry. Both writers agree, however, that the overiying rock-sheets of the Plessurgebirge have been brought into the area from a distance; and that is the point which interests the watchers of the tourney.

Dr. W. Hammer, in a review of the above paper (Verhandl. d. k.k. geol. Reichsanstalt, 1906, p. 383), evidently regards it as an attempt to put an old wine of good quality into new and uncertain bottles. But Herr G. Steinmann adopts Hoek's typical landscape of the four overthrust sheets above Parpan in his "Geologische Probleme des Alpengebirgs" (p. 40), and he has had ample opportunity of discussing the structure with the author. Steinmann's paper, published by the Deutscher und Österreichischer Alpenverein at Innsbruck in 1906 (Bd. 37 of their Zeitschrift), is a delightful exposition of the older and later views, beginning with the Juras and ending in the east of Switzerland, and is written for the ordinary traveller as well as for the geologist. The landscapes, in which the beds are duly labelled, are accompanied by an admirable series of sections, often showing the two rival readings, and gathered from various authors. Steinmann's own sections show clearly the stages of growth which are held to have culminated in the system of overfolds in Switzerland. This lucid paper seems to us perfect for its purpose, and the author is able, in his separately issued copies, to reproduce Dr. von Seidlitz's panorama from the Künihorn, which was published in part only in the Zeitschrift des Alpenvereins.

Herr Schardt himself has furnished, in the Verhandlungen der Schweizerischen Naturforschenden Gesellschaft, St. Gallen meeting, 1906, p. 308, a welcome account of "die modernen Anschauungen über den Bau und die Enstehung des Alpengebirges." Already this distinguished author suffers from an extremist group of followers, and he humorously characterises some of Termier's work as an exhibition of "Ultranappismus." The coloured sections illustrating Schardt's paper supplement this very clear exposition of his views. On p. 343 he emphasises the importance of gravitational sliding in producing certain features of steeply elevated and compressed folds, and points out that this influence has been too often underestimated.

Travellers in the most familiar part of Europe will also profit greatly by Herr A. Baltzer's " Das Berneroberland und Nachbargebiete" (Berlin: Gebrüder Borntraeger, I906, pp. $x v+347)$. The price of this handy book, 12.50 marks, includes a general volume, which has not yet reached us, though it was announced to appear during last winter. Rothpletz's work on the overfolded area of the Rhætic Alps, to which Hoek refers in the paper above noticed, has been published in the same "Sammlung geologischer Führer." Baltzer's volume starts in the Bernese Juras, among the romantic cluses, guides the pedestrian of geological tastes to the typical sections around Grindelwald, and brings him back by the St. Gothard railway and Lucerne. The illustrations are not always so neat as those of Steinmann, but cover a great amount of detail. The transparent sheets on which the names of the rock-layers are printed, which are used as indexes to several of the photographs, strike us as a little awkward in a book that must be used in all weathers in the field. Among the many useful diagrams is one (Fig. 69) showing the folded strata as viewed from the steamer on both sides of the lake of Uri.

Dr. C. Sandberg (Transactions of the Geolugical Society of South Africa, vol. ix., Johannesburg, 1906, p. 82) gives a new reading of the folded structure underlying "the innocent looking, softly undulating Karroo Formation " in the Prince Albert district of Cape Colony. The country, with its bare kopjes and its abundance of rock-exposures, lends itself to stratigraphical investigation. The Tygerberg shows on its south side the Witteberg series resting on the Dwyka conglomerate, which properly overlies it, while the Dwyka series occurs again on the north side of the hill. This can be explained by fan-structure, the Witteberg series coming up along a local anticline, which has expanded southward as an overfold. Though various authors show various dips, the anticlinal view has been generally accepted. Dr. Sandberg, however, quoting the magic names of Schardt, Lugeon, and Termier, reads the structure as the downward-turned, or, shall we say, pseudosynclinal, end of an overpushed anticline, the root of which lies away in the $Z$ wartebergen to the south. Mr. A. W. Rogers, who is invoked by the writer; points out that a section quoted from him in support does not touch the Tygerberg, and he evidently prefers the older view for the present (Proceedings to accompany the above volume, 1907, p. liii.). But Dr. Sandberg's paper serves as a fresh indication of the keenness and vitality that prevail in South African geology.

It is evident that very few geologists now doubt that overfolds occur in the earth's crust, whereby strata are moved from their place of deposition over distances amounting to even roo kilometres. If we grant ten miles for such movements in the north of Scotland, we do not find it unreasonable to allow seventy miles of overthrusting in the more crumpled region of the Alps (see Sir A. Geikie's remarks, Abstracts of the Proceedings of the Geol. Soc. of London, April ro, p. 67). But the admission raises serious questions as to what happens in the foundations underlying these compressed areas of the crust. Dr. Ampferer, in a lengthy and closely reasoned paper on "Das Bewegungsbild von Faltengebirgen" (Jahrb. der k.k. geol. Reichsanstalt, Bd. 1vi., 1906, pp. 539-622), rejects the theory that localised crumpling is due to the approach of great earth-blocks in the contracting crust. He urges, moreover, that there is nothing in any complex group of rocks, such as we ordinarily find folded together in a mountain-chain, to account for the folding in that particular locality. The local structure determines the details of the architecture (p. 607), but the position of the chain on the earth must be referred to the nature of the plastic foundation, the "Untergrund." The composition of the earth's interior is by no means uniform (pp. 608 and 609 ), and both physical and chemical changes in it may produce considerable alterations of volume in one portion or another. These alterations are manifested at the surface, in the sensitive skin of the earth, as local sulvsidences or elevations. The vertical movements of the foundation lead to gravitational sliding, which affects the overlying skin (p. 60I), and it is suggested that the folded mountain-chains are formed along lines of more or less intense vertical upheaval, from which the fundamental masses then flow away sideways, producing the overfolds and crumplings that we perceive upon the surface. The underflow, the "Unterströmung," is thus Ampferer's main cause of surface-folding, and changes in the living and mobile "Untergrund " determine where "Unterströmung" shall occur.

We trust that in these few words we have correctly represented Dr. Ampferer; for the paper is not an easy one, and the absence of references to the details shown in many of the diagrams renders these of little help as illustrations. Yig. $4 \mathrm{I}$, however, on p. $6 \mathrm{I} x$, shaws suggestively how the irregularities of the foundation or "Untergrund" may be ascertained by a comparison of the geological history of areas on the earth's surface. Areas with similar foundations may be expected to subside together or to be elevated together during geological time. It is easier to estimate the amount of subsidence that took place during any epoch than the amount of elevation, the latter being marked by no characteristic sediments; but we may hope eventually to represent the history of an area by a curve

No. 1973, vOL. 76] 
rising or falling in reference to a datum-line, the timescale being indicated on the latter. Prof. Steinmann, in the paper above noticed, has employed similar curves for various regions in the Alps. Dr. Ampferer holds that a similarity in the curves for two or more areas would imply a general similarity in the foundation. This seems to leave out of count Mr. Osmond Fisher's suggestion of convection-currents in a liquid interior, which might produce considerable local differences in the curves; but the absence of all reference to previous workers, except a passing one to Schardt's and Lugcon's theory of overfolding, makes it uncertain how far Dr. Ampferer wishes to link himself with his predecessors. While admitting (p. 620) that his criticism has been largely of a destructive order, he feels hopeful that future research may make us better acquainted with the "Untergrund."

Dr. Ampferer's paper was written in March, 1906, but was not issued until December. Meanivhile, Mr. R. A. Daly had published a paper on abyssal igneous injection as a causal condition and as an effect of mountainbuilding (American Journ. of Sci., vol. xxii., September, 1906, p. 195). Ampferer does not believe in geosynclinals and subsequent lateral compression; but it is precisely these that Daly sets out to explain. He urges that the underlying molten magma, which he believes to be of basaltic composition, is always ready to leap into any cracks that arise in the plastic layer above it and in the "shell of tension" in the lower portion of the crust. Cracks may arise in the plastic layer by the effects of tidal torsion on the crust, and in the shell of tension by the general contraction due to cooling. The igneous mass in the great dykes thus produced, so long as it remains liquid, exercises a hydrostatic pressure on its walls, and forces them further apart. Here we have a cause that may close up other cracks in the shell of tension, and the total lateral creep " involves a strong downward pull exerted on the shell of compression," i.e. that part of the crust above the level of no strain. The resulting geosynclinal area finally becomes weakened, as sediments accumulate in it and its underlying rocks are bent down into hotter regions; and then, in some way which is rather lightly dealt with, an "orogenic collapse" takes place, and a mountain-chain begins to rise. The increase in bulk of the crust by magmatic injection, which was, by the by, well pointed out by Mr. Osmond Fisher, is urged as an additional cause of its crumpling, and the hydration of its minerals gives similar assistance. The shearing apart of the shell of compression and the shell of tension "during the orogenic revolution releases the tensions still unrelieved in the underlying shell," and allows of further abyssal injection on a large scalc. The location and elongation of mountain-chains and geosynclinals are all (p. 216) related to special zones of abyssal injections from the substratum. Here we see Mr. Daly looking, like Dr. Ampferer, for final causes in the "Untergrund," and with this point of agreement we must for the moment rest content.

Still more recently (March, 1907), Dr. L. Waagen publishes in the Verhandlungen der k.k. geologischen Reichsanstalt a general review of the relations of ocean-basins and mountain-chains. He finds the origin of folding in the subsidence of continental masses, and the continued sinking of the moving Hinterland of a chain may bring this region below sea-level, and so promote an interchange between continental and oceanic areas. Marine transgressions (p. I2I) are thus the natural accompaniments of epochs of considerable mountain-building.

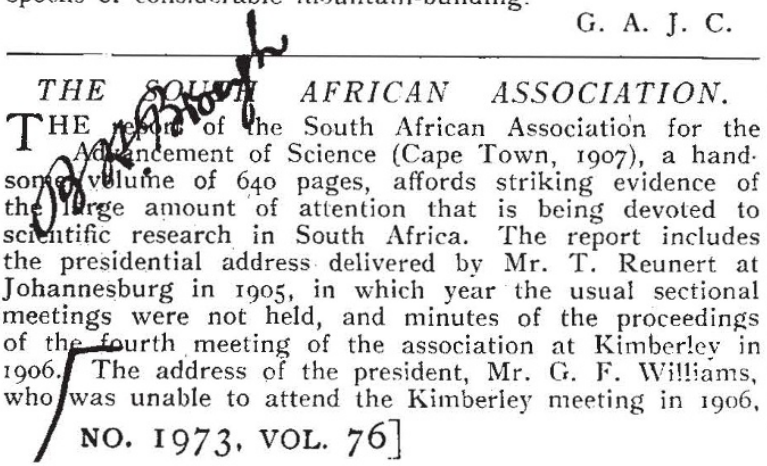

contains an interesting historical sketch of the settyef frent of the Cape, of the adventurous spirit of the PfNuse, of the influence of the Dutch pioneers the foundation of the mining indurs ry of to-day.

The president of Section A, Mr J. R. Sutton, gave a valuable summary of our present knowledge of the diurnal variation of barometric pressures which may be considered as the fundamental problem in meteorology-the rise and fall of the barometer twice a day, the precise cause of which has never been satisfactorily explained. After referring to the efforts of Herschel, Dove, and others, the author pointed out that Dr. Buchan made a material advance in distinguishing between the weight and elasticity of the air. Perhaps the most important contribution to the subject is due to Prof. J. Hann, who by classifying and generalising the harmonic elements for a great number of stations succeeded in establishing some noteworthy results. Among the various papers read in this section, some of which have been published elsewhere, we may specially mention:-(I) Anticyclones and their influence on South African weather, by Colonel H. E. Rawson. An examination of the charts published by the London Meteorological Office, and of other data, showed that the weather in South Africa is under the direct influence of the movements of two great anticyclonic systems lying to the west and cast. (2) The barometer in South Africa, by $\mathrm{Mr}$. R. T. A. Innes. The author states that the annual variation of the barometer consists of a well-marked single oscillation, pressure being greatest in winter and least in summer. (3) Variability of temperature in South Africa by $\mathrm{Mr}$. J. R. Sutton, as represented by three typical stations, showing the mean difference between the temperatures of one day and the next. Prof. J. Milne contributed a paper on the observation of earthquakes and other earth movements, and Prof. R. A. Lehfeldt one on accelerations of gravity at Johannesburg.

At the various sectional meetings sixty papers were read, which are published in full or in abstract. Amogg these, noteworthy papers dealing with matters of local interest are, in addition to those already mentioned :-R $\int_{\mathrm{H}}$. A Junod, on the theory of witcheraft amos adn African natives; Rev. F. Reuter, on northern J far oul thnology Mr. A. W. Rogers, on the glacip. beds of the Griqua Town series; Mr. R. H. Rafth, fon the petrography of the Kimberley district; Mf. O. P. Mennell, on the Somabula diamond field of Rhodesia; Mr. J. P. Johnson, on the Stone age of South Africa; Mr. F. A. Hurley and Mr. C. D. H. Braine, on irrigation in South Africa; Mr. K. A. H. Hought, on native education in its higher branches; and Mr. T. Lowden, on the piace of manual training in South African education.

Of the sectional presidential addresses, that by $\mathrm{Mr}$. Sidney J. Jennings, on wastes in mining, waste of thought, waste of labour, and waste of material, should be mentioned. Nothing has proved so efficacious for the prevention of waste of thought as the free interchange of ideas made possible by the numerous societies and associations. Centralised management can also be made to perform a valuable function in preventing thought-waste. In preventing waste of labour, the fundamental difficulties lie in the untrained condition of the Kafir for manual labour. and in the ineptitude of many white overseers for transforming a semi-savage population into an industrial one. The best prevention of waste of stores is the continued thought of the management combined with the loyal and interested cooperation of the men.

An account of a discussion on university education in South Africa is contained in the report. The discussion was opened by Prof. Lyster Jameson with a brief survey of the past history and present position of university education in South Africa, followed by a summary of the more obvious remedies for the present unsatisfactory state of affairs. There is a single university, the University of the Cape of Good Hope, an examining body pure and simple. In addition to the University, several institutions calling themselves colleges have arisen. In the Transvaal the only. institution seriously doing university work is the Transvaal University College, which was founded as a full faculty of mining and engineering, adding its arts department at a later date. However great the dis- 